\title{
Reproducible challenge model to investigate the virulence of Flavobacterium columnare genomovars in rainbow trout Oncorhynchus mykiss
}

\author{
B. R. LaFrentz ${ }^{1, *}$, S. E. LaPatra ${ }^{2}$, C. A. Shoemaker ${ }^{1}$, P. H. Klesius ${ }^{1}$ \\ ${ }^{1}$ United States Department of Agriculture-Agricultural Research Service (USDA-ARS), \\ Aquatic Animal Health Research Unit, 990 Wire Road, Auburn, Alabama 36832-4352, USA \\ ${ }^{2}$ Clear Springs Foods, Research Division, PO Box 712, Buhl, Idaho 83316, USA
}

\begin{abstract}
Flavobacterium columnare is a Gram-negative bacterium that causes columnaris disease and has significant economic impacts on aquaculture production worldwide. Molecular analyses have demonstrated that there is genetic diversity among $F$. columnare isolates. A review of the published literature that used restriction fragment length polymorphism analysis of the $16 \mathrm{~S}$ rRNA gene revealed that all isolates typed from salmonids were Genomovar I. Our objective was to develop a laboratory challenge model for F. columnare in rainbow trout Oncorhynchus mykiss (Walbaum) and use the model to determine the virulence of Genomovar I and II isolates. Six F. columnare isolates were obtained from rainbow trout experiencing losses due to columnaris disease and were determined to be Genomovar I. Three of these were chosen for a preliminary assessment of virulence, and isolate 051-10-S5 was chosen for additional experiments to determine the reproducibility of the waterborne challenge model. In 2 independent experiments, cumulative percent mortalities (CPM) were $49 \pm 10 \%$ and $50 \pm 19 \%$. Challenge of rainbow trout with Genomovar I and II isolates demonstrated a difference in the CPM, with the Genomovar II isolates inducing significantly higher CPM. This reproducible waterborne challenge model for columnaris disease in rainbow trout will be useful to investigate host-pathogen interactions, vaccine development, and other potential control strategies. This research also provides a basis for further defining the molecular diversity and virulence associated with F. columnare genomovars in rainbow trout and other salmonid species.
\end{abstract}

KEY WORDS: Flavobacterium columnare - Rainbow trout - Genomovar - Columnaris disease · Challenge model

Resale or republication not permitted without written consent of the publisher

\section{INTRODUCTION}

Columnaris disease was first described in 19171919 in the United States by Davis (1922), and the name of the causative bacterial agent was proposed as Bacillus columnaris, although culture of the microorganism was unsuccessful. In general, clinical signs of columnaris disease are easily recognized and include frayed fins, depigmented lesions on the skin, and necrotic gill lesions. Wet mounts of gill tissue or skin lesions from diseased fish reveal long slender rods with gliding movement, and the cells aggregate into columns of cells, thus the name columnaris disease. In 1944, the Gram-negative bacterium responsible for columnaris disease was successfully cultured in vitro and was renamed Chondrococcus columnaris (Ordal \& Rucker 1944). Since then, the bacterium has been reclassified several times and is 
currently described as Flavobacterium columnare (Bernardet et al. 1996).

The significance of columnaris disease was evident when it was first described due to its ability to affect numerous warm- and cold-water fish species (Davis 1922), and currently it continues to impact various cultured and wild (Morris et al. 2006) species of fish. Flavobacterium columnare is considered one of the most important bacterial pathogens impacting salmonid production in Finland (Suomalainen et al. 2005) and channel catfish Ictalurus punctatus production in the United States (Wagner et al. 2002). Recently, columnaris disease has emerged in the Chilean aquaculture industry as the production of coho salmon Oncorhynchus kisutch and rainbow trout O. mykiss has intensified (Avendaño-Herrera et al. 2011). Additionally, in recent years there has been an increase in the incidence of columnaris disease in the commercial rainbow trout industry in Idaho, USA (S. E. LaPatra pers. obs.).

Molecular analyses have demonstrated that there is genetic diversity among Flavobacterium columnare isolates. Two or 3 different genetic groups have been described depending on the method used and isolates examined (Triyanto \& Wakabayashi 1999, Arias et al. 2004, Thomas-Jinu \& Goodwin 2004, Darwish \& Ismaiel 2005, Olivares-Fuster et al. 2007b, Soto et al. 2008). The most common method used to type $F$. columnare isolates is restriction fragment length polymorphism (RFLP) analysis of the 16S rRNA gene. Triyanto \& Wakabayashi (1999) applied this technique to 23 isolates originating from different fish species and geographic locations, and the results suggested 3 different genomic groups or genomovars. Similar results were obtained by Darwish \& Ismaiel (2005). Olivares-Fuster et al. (2007b) optimized conditions for the technique and suggested that subgroups existed within Genomovars I and II and described Genomovars I, I-B, II, and II-B.

A review of the literature revealed an interesting observation concerning the molecular typing of Flavobacterium columnare isolates recovered from salmonids. All salmonid isolates that have been typed to date using the RFLP analysis of the 16S rRNA gene and published are Genomovar I (Triyanto \& Wakabayashi 1999, Michel et al. 2002, Arias et al. 2004, Schneck \& Caslake 2006, Suomalainen et al. 2006a, 2006b, Avendaño-Herrera et al. 2011). These isolates originated from geographically diverse regions includ- ing Chile, Finland, France, and the United States and from different fish species in the family Salmonidae, including rainbow trout, coho salmon, Chinook salmon Oncorhynchus tshawytscha, sockeye salmon or kokanee O. nerka, Atlantic salmon Salmo salar, brown trout $S$. trutta, arctic charr Salvelinus alpinus, brook trout $S$. fontinalis, and grayling Thymallus thymallus. This observation suggests there is a host-specific association between Genomovar I F. columnare isolates and salmonids and may indicate that Genomovar I isolates are more virulent than Genomovar II isolates in salmonids. Additionally, Michel et al. (2002) suggested that the likelihood of Genomovar II isolates infecting salmonids is low, based on the observation of no mortality following challenge of rainbow trout with a Genomovar II isolate. In the present study, a reproducible columnaris disease challenge model was developed in rainbow trout and used to test the hypothesis that Genomovar I $F$. columnare isolates were more virulent in rainbow trout than Genomovar II isolates because of their apparent species specificity.

\section{MATERIALS AND METHODS}

\section{Bacteria and culture conditions}

Six presumptive Flavobacterium columnare isolates were obtained from moribund rainbow trout at production facilities experiencing losses due to columnaris disease (Table 1). Isolate 031-10-S1 was obtained from gill tissue, while the other 5 isolates were obtained from kidney tissue. The isolates were confirmed as F. columnare by analysis of fatty acid profiles and PCR as described by Shoemaker et al. (2005) and Welker et al. (2005), respectively. The F.

Table 1. Flavobacterium columnare isolates used in this study. ${ }^{\mathrm{T}}$ : type strain

\begin{tabular}{|lcccc|}
\hline Isolate & Year of isolation & Fish host & Origin & Genomovar \\
\hline 023-08-2 & 2008 & Rainbow trout & Idaho (USA) & $\mathrm{I}^{\mathrm{a}}$ \\
023-08-6 & 2008 & Rainbow trout & Idaho (USA) & $\mathrm{I}^{\mathrm{a}}$ \\
030-10-S5 & 2010 & Rainbow trout & Idaho (USA) & $\mathrm{I}^{\mathrm{a}}$ \\
031-10-S1 & 2010 & Rainbow trout & Idaho (USA) & $\mathrm{I}^{\mathrm{a}}$ \\
031-10-S5 & 2010 & Rainbow trout & Idaho (USA) & $\mathrm{I}^{\mathrm{a}}$ \\
051-10-S5 & 2010 & Rainbow trout & Idaho (USA) & $\mathrm{I}^{\mathrm{a}}$ \\
ATCC 23463 & 1955 & Chinook salmon & Washington (USA) & $\mathrm{I}^{\mathrm{a}, \mathrm{b}}$ \\
ARS-1 & 1996 & Channel catfish & Alabama (USA) & $\mathrm{I}^{\mathrm{b}}$ \\
AL-02-36 & 2002 & Largemouth bass & Alabama (USA) & $\mathrm{II}^{\mathrm{a}, \mathrm{b}}$ \\
ALG-00-530 & 2000 & Channel catfish & Alabama (USA) & $\mathrm{II}^{\mathrm{b}}$ \\
LSU & 1999 & Channel catfish & Louisiana (USA) & $\mathrm{II}^{\mathrm{b}}$ \\
a Results from present study; ${ }^{\mathrm{b}}$ results from Arias et al. (2004) & \\
\hline
\end{tabular}


columnare type strain (ATCC 23463; Genomovar I) and a channel catfish isolate (AL-02-36; Genomovar II) were used as genomovar controls for the RFLP analyses (Table 1). Two Genomovar I isolates (051-10-S5 and ARS-1) and 2 Genomovar II isolates (ALG-00-530 and LSU) were used in the challenge experiment to determine the virulence in rainbow trout (Table 1).

Stock suspensions of the isolates were maintained at $-80^{\circ} \mathrm{C}$ in $20 \%$ glycerol and were used to inoculate cultures. Flavobacterium columnare isolates were cultured in $25 \mathrm{ml}$ of modified Shieh broth (LaFrentz \& Klesius 2009) for $24 \mathrm{~h}$ on a shaker set at $28^{\circ} \mathrm{C}$ and $175 \mathrm{rpm}$. The optical density at $540 \mathrm{~nm}$ was adjusted to 1.0 and used for bacterial challenges. The number of viable colony forming units (cfu) $\mathrm{ml}^{-1}$ was determined by spread plating $50 \mu \mathrm{l}$ volumes of 10 -fold serial dilutions (in duplicate) onto modified Shieh agar plates. Plates were incubated for $48 \mathrm{~h}$ at $28^{\circ} \mathrm{C}$, and colonies were counted and averaged to enumerate the $\mathrm{cfu} \mathrm{ml} \mathrm{m}^{-1}$ using standard procedures.

\section{RFLP analysis of 16S rRNA gene}

Total DNA was extracted from the Flavobacterium columnare isolates using a Qiagen DNeasy Blood and Tissue kit according to the manufacturer's protocol for Gram-negative bacteria, and the total DNA concentration was measured using a NanoDrop ND1000 spectrophotometer. The 16S rRNA gene was amplified from the $F$. columnare isolates by PCR using the universal primers $20 \mathrm{~F}$ and $1500 \mathrm{R}$, and resultant PCR products were digested as described by Triyanto \& Wakabayashi (1999) with the following modifications. PCR was performed using the HotStarTaq Plus Master Mix kit (Qiagen), and the final concentrations of each component in the $40 \mu \mathrm{l}$ reactions were as follows: 1× HotStarTaq Plus Master Mix, $0.4 \mu \mathrm{M}$ each primer (20F, 1500R), $1 \times$ CoralLoad Concentrate, and $100 \mathrm{ng}$ total DNA. PCR amplification was performed with a Primus HTD thermocycler (MWG AG Biotech), and the following cycling protocol was used: 1 cycle of 5 min at $95^{\circ} \mathrm{C}_{i} 35$ cycles of $30 \mathrm{~s}$ at $94^{\circ} \mathrm{C}, 45 \mathrm{~s}$ at $55^{\circ} \mathrm{C}$, and $60 \mathrm{~s}$ at $72^{\circ} \mathrm{C}$; final cycle of $10 \mathrm{~min}$ at $72^{\circ} \mathrm{C}$. PCR products from each isolate were digested with HaeIII (New England Biolabs) restriction endonuclease according to the manufacturer's directions. Digested fragments were detected by agarose gel electrophoresis $(2 \% \mathrm{w} / \mathrm{v})$ in Tris-acetateEDTA (TAE) buffer. Gels were precast with $1 \times$ SYBR Safe DNA gel stain (Invitrogen) and DNA fragments were visualized using UV transillumination.

\section{Fish and rearing conditions}

Rainbow trout fry ( $20 \mathrm{~d}$ post hatch; 300 degree days in age) were obtained from Clear Springs Foods and were reared according to standard practices. Fish were maintained in $57 \mathrm{l}$ aquaria supplied with $1.01 \mathrm{~min}^{-1}$ of chilled $\left(16^{\circ} \mathrm{C}\right)$ de-chlorinated municipal water and supplemental aeration was provided by air stones. Fish were fed 3-4\% of their body mass daily with appropriately sized fish feed (Aquamax Grower, PMI Nutrition International). Prior to bacterial challenges, gill and head kidney tissue from 10 fish were plated onto modified Shieh agar containing $1 \mu \mathrm{g} \mathrm{ml}^{-1}$ tobramycin (Decostere et al. 1997) and incubated at $28^{\circ} \mathrm{C}$ for $72 \mathrm{~h}$. None of the fish sampled were culture positive for Flavobacterium columnare. Feed was restricted from fish for $24 \mathrm{~h}$ prior to bacterial challenges and fish were maintained as described above, with the exception that aquaria were supplied with $0.51 \mathrm{~min}^{-1}$ of chilled water. All procedures utilizing fish were approved by the USDA-ARS AAHRU Institutional Animal Care and Use Committee.

\section{Development of challenge model}

A preliminary challenge was conducted to identify a suitable Flavobacterium columnare isolate that could be used for developing a reproducible challenge model. Three isolates obtained from rainbow trout (023-08-6, 031-10-S5, and 051-10-S5) were tested. Single groups of 10 fish (mean mass $=0.74 \mathrm{~g}$; 748 degree days in age) each were challenged by immersion for $1 \mathrm{~h}$ in $1 \mathrm{l}$ of water containing $25 \mathrm{ml}$ of each respective isolate at an optical density of 1.0 at $540 \mathrm{~nm}$. The challenge doses in $\mathrm{cfu} \mathrm{ml}^{-1}$ were not determined for this challenge. A fourth group of 10 fish was mock-challenged by immersion for $1 \mathrm{~h}$ in $1 \mathrm{l}$ of water containing $25 \mathrm{ml}$ sterile modified Shieh broth. Aeration during the challenge was provided by air stones. Following challenge, the fish and challenge water were poured into separate pre-filled 571 aquaria. Dead fish were removed and recorded twice daily for $17 \mathrm{~d}$, and reisolation of $F$. columnare was attempted on at least $20 \%$ of the daily mortalities from each tank by inoculating gill and head kidney tissue onto modified Shieh agar containing $1 \mu \mathrm{g} \mathrm{ml}^{-1}$ tobramycin (Decostere et al. 1997). Plates were incubated at $28^{\circ} \mathrm{C}$ for $48 \mathrm{~h}$ and then examined for yellowpigmented, rhizoid, and tightly adherent colonies phenotypic of $F$. columnare.

Based on the results of the preliminary challenge, Flavobacterium columnare isolate 051-10-S5 was 
chosen for subsequent challenges. Two independent challenges (Trials 1 and 2) were performed. In Trial 1, triplicate groups of 25 fish (mean mass $=1.1 \mathrm{~g} ; 908$ degree days in age) were challenged by immersion for $1 \mathrm{~h}$ in $1 \mathrm{l}$ of water containing $1.6 \times 10^{7} \mathrm{cfu} \mathrm{ml}^{-1}$ or were mock-challenged by immersion for $1 \mathrm{~h}$ in $1 \mathrm{l}$ of water containing $25 \mathrm{ml}$ sterile modified Shieh broth. Trial 2 was conducted identically with the exception that the mean mass of fish was $1.7 \mathrm{~g}$ (1244 degree days in age) and the challenge dose was determined to be $1.7 \times 10^{7} \mathrm{cfu} \mathrm{ml}^{-1}$. Aeration during the $1 \mathrm{~h} \mathrm{im-}$ mersion was provided by air stones. In both trials, dead fish were removed and recorded twice daily for $27 \mathrm{~d}$, and reisolation of $F$. columnare was performed as described in the preliminary challenge.

\section{Virulence of Genomovar I and II isolates}

The challenge model was then used to compare the virulence of Genomovar I and II Flavobacterium columnare isolates in rainbow trout. Two Genomovar I isolates (ARS-1 and 051-10-S5) and 2 Genomovar II isolates (ALG-00-530 and LSU) were selected. The challenge was conducted as described in Trials 1 and 2 (triplicate groups of 25 fish per isolate), with the exception that the mean mass of fish was $2.0 \mathrm{~g}(1612$ degree days in age) and the challenge dose for each isolate ranged from 1.2 to $3.5 \times 10^{7} \mathrm{cfu} \mathrm{ml}^{-1}$. Dead fish were removed and recorded twice daily for $24 \mathrm{~d}$, and reisolation of $F$. columnare was performed as described in the preliminary challenge.

\section{Statistical analyses}

The mean cumulative percent mortality (CPM) data from the Flavobacterium columnare challenge using the Genomovar I and II isolates were analyzed by a 1-way ANOVA with Tukey's test for pairwise comparisons. Differences were considered significant when $\mathrm{p}<0.05$. Data were analyzed and graphically represented using GraphPad Prism (version 5.03).

\section{RESULTS}

\section{RFLP analysis of 16S rRNA gene}

The results of the 16S rRNA genotyping demonstrated that the 6 Flavobacterium columnare isolates obtained from moribund rainbow trout in the United States were determined to be Genomovar I (Table 1,
Fig. 1). The sizes and pattern of DNA fragments obtained following endonuclease digestion matched those of the F. columnare ATCC 23463 isolate, which has been previously typed as a Genomovar I isolate (Fig. 1).

\section{Preliminary challenge}

Three different mortality patterns were obtained in rainbow trout following immersion challenge with the Genomovar I Flavobacterium columnare isolates obtained from moribund rainbow trout (Fig. 2). Challenge with isolate 023-08-6 resulted in an acute columnaris infection in rainbow trout with $100 \%$ CPM by $2 \mathrm{~d}$ post challenge (dpc). Challenge with iso-

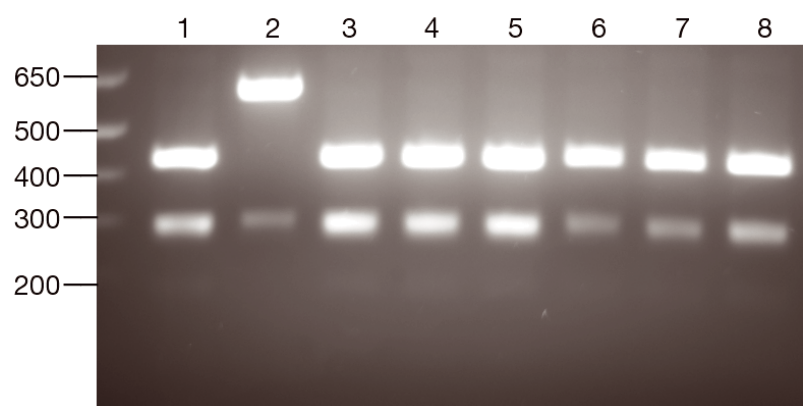

Fig. 1. Flavobacterium columnare. Restriction profiles of 16S rRNA gene amplified from $F$. columnare isolates and digested with HaeIII. Lane 1: ATCC 23463 (Genomovar I); Lane 2: AL-02-36 (Genomovar II); Lane 3: 023-08-2; Lane 4: 023-08-6; Lane 5: 030-10-S5; Lane 6: 031-10-S1; Lane 7: 03110-S5; Lane 8: 051-10-S5. Molecular weight markers (bp) are indicated to the left of the gel

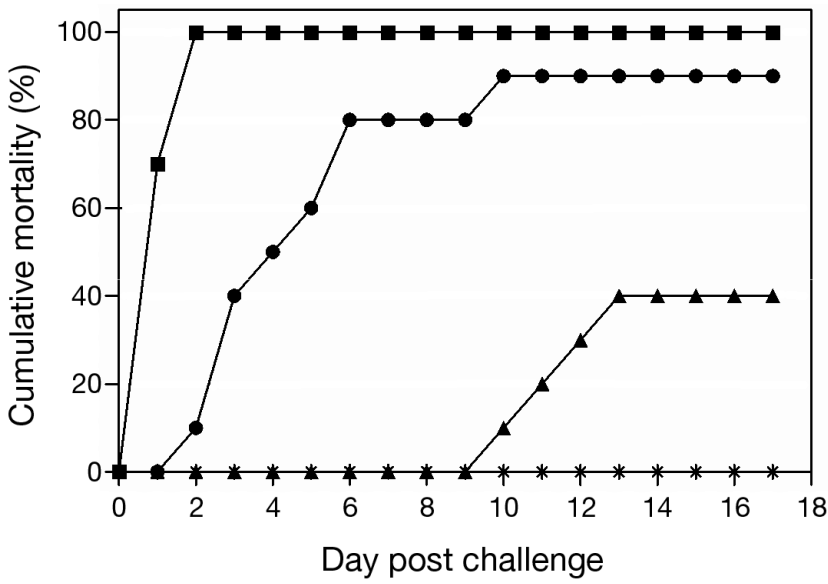

Fig. 2. Oncorhynchus mykiss. Mean cumulative percent mortality of rainbow trout (mean mass $=0.74 \mathrm{~g} ; 748$ degree days in age) following challenge with Flavobacterium columnare. Single groups of 10 fish were challenged by immersion with isolates originating from rainbow trout: 023-08-6 (ם), 051-10S5 (๑), 031-10-S5 ( $\boldsymbol{\Delta})$, or mock-challenged (*) 
late $051-10$-S5 resulted in CPM of $90 \%$ in which mortality began at $2 \mathrm{dpc}$ and ceased at $10 \mathrm{dpc}$. Challenge with isolate 031-10-S5 also induced columnaris disease; however, mortality was delayed and occurred between 10 and $13 \mathrm{dpc}$, with a final CPM of $40 \%$ (Fig. 2). There were no mortalities in the mock-challenged group. Clinical signs of fish that were examined included gill necrosis, frayed caudal fins, and depigmented gray lesions of the caudal peduncle. In some fish, the depigmented lesions were located bilaterally around the dorsal fin (saddleback), and in others the location of the lesion varied on the caudal peduncle. F. columnare was reisolated from $100 \%$ $(20 / 20)$ of the fish examined. Isolate 051-10-S5 was selected for additional challenge experiments due to the sub-acute columnaris infection in which mortality occurred over the course of $9 \mathrm{~d}$, and the final CPM was greater than $60 \%$.

\section{Challenge reproducibility}

Two independent challenges were performed to determine the reproducibility of the challenge mortality and the variation in mortality between replicate groups using Genomovar I isolate 051-10-S5 (Fig. 3). In Trials 1 and 2, the final mean CPM values for each challenge were similar (49 and $50 \%$, respectively), although slightly different mortality patterns were observed. In Trial 1, mortality increased more rapidly early in the challenge compared with Trial 2 (Fig. 3). The standard deviations between replicate groups of fish challenged in Trials 1 and 2 was \pm 10 and $19 \%$, respectively. There were no mortalities in the mock-

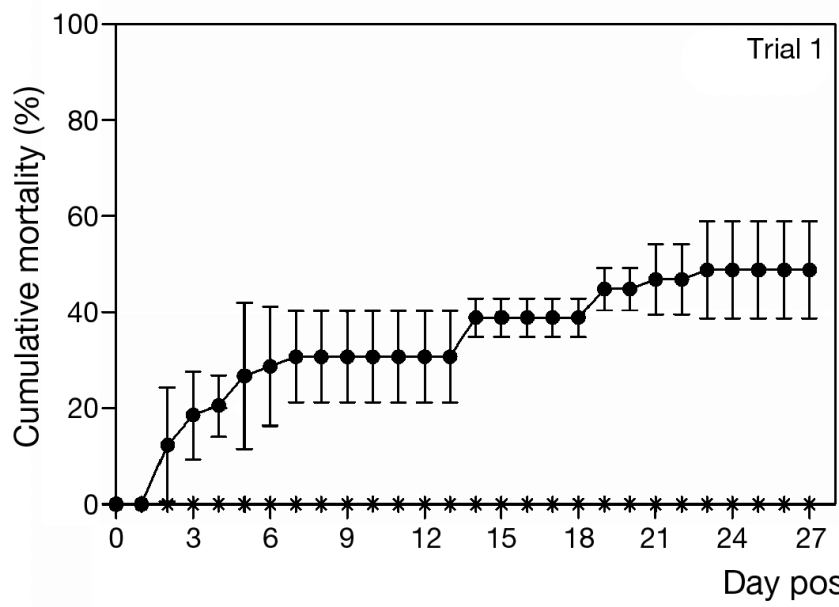

challenged control groups in either of the two trials. Clinical signs of the fish examined were similar to those observed in the preliminary challenge, and $F$. columnare was reisolated from $100 \%(24 / 24 ; 37 / 37)$ of the fish examined from each trial.

\section{Virulence of Genomovar I and II isolates}

Rainbow trout challenged with Genomovar I isolates of Flavobacterium columnare resulted in mean CPM values of 49 and $23 \%$ for the $051-10-S 5$ and ARS-1 isolates, respectively (Fig. 4). The mean CPM obtained with both Genomovar I isolates was significantly lower $(p<0.05)$ than those obtained with the ALG-00-530 and LSU Genomovar II isolates, which were 96 and $91 \%$, respectively (Fig. 4). There were no mortalities in the mock-challenged control group, and $F$. columnare was reisolated from $100 \%(68 / 68)$ of the fish examined.

\section{DISCUSSION}

To determine the virulence of Genomovar I and II Flavobacterium columnare isolates in rainbow trout, a reproducible columnaris challenge model needed to be developed. Such models have been developed for rainbow trout in Finland (Suomalainen et al. 2006b, Kunttu et al. 2009). However, in those studies, the water temperatures used ranged from 24 to $25^{\circ} \mathrm{C}$, which is higher than the constant $15^{\circ} \mathrm{C}$ spring water used for the majority of rainbow trout production in the United States. It was assumed that the challenge

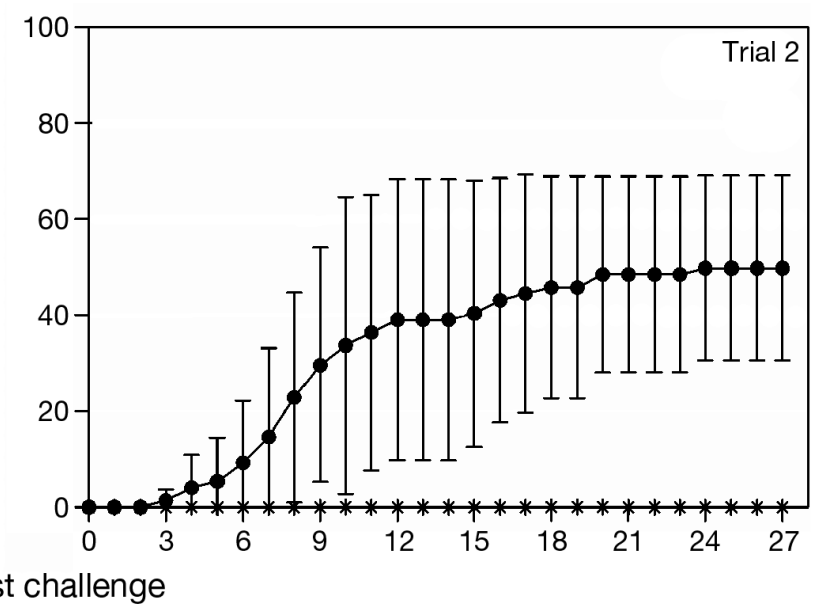

Fig. 3. Oncorhynchus mykiss. Mean cumulative percent mortality of rainbow trout following 2 independent Flavobacterium columnare challenges (Trials 1 and 2). The mean masses of fish were $1.1 \mathrm{~g}$ (908 degree days in age) and $1.7 \mathrm{~g}$ (1244 degree days in age) in Trials 1 and 2, respectively. Triplicate groups of 25 fish were challenged by immersion with $F$. columnare isolate 051-10-S5 $(\bullet)$ or mock-challenged (*). Error bars indicate standard deviation 


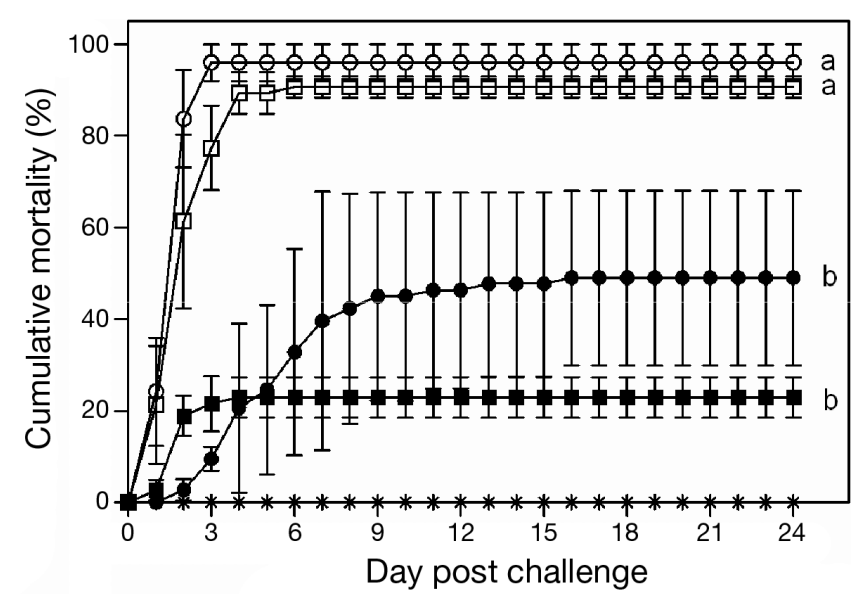

Fig. 4. Oncorhynchus mykiss. Mean cumulative percent mortality of rainbow trout (mean mass $2.0 \mathrm{~g} ; 1612$ degree days in age) following challenge with Genomovar I $(\bullet, 051-10-S 5 ; \quad$, ARS-1) and Genomovar II (O, ALG-00-530; $\square$, LSU) isolates of Flavobacterium columnare, or mock-challenged (*). Triplicate groups of 25 fish were challenged with each isolate or mock-challenged, and error bars indicate standard deviation. Mean cumulative percent mortality values with different letters indicate a significant difference at $\mathrm{p}<0.05$

conditions used by the aforementioned authors would have to be adapted to induce columnaris disease in rainbow trout maintained at $15^{\circ} \mathrm{C}$ because the severity of columnaris disease is generally greater at higher water temperatures.

Based on the preliminary challenge using $0.74 \mathrm{~g}$ (748 degree days in age) rainbow trout, Flavobacterium columnare isolate 051-10-S5 was chosen for further studies due to the sub-acute columnaris infection in which mortality occurred over the course of $9 \mathrm{~d}$, and the final CPM was greater than $60 \%$. Two subsequent independent challenges using 1.1 and $1.7 \mathrm{~g}$ (908 and 1244 degree days in age, respectively) rainbow trout resulted in final CPM values of 49 and $50 \%$, respectively. Additionally, this isolate was included in the genomovar virulence comparison challenge using $2.0 \mathrm{~g}$ (1612 degree days in age) fish, and the final CPM was $49 \%$. The results of these challenges demonstrated the ability to reproduce the CPM in independent challenges. If a higher mean CPM is required for future use of this challenge model, it may be necessary to optimize the challenge model using higher doses of $F$. columnare and/or expose the fish for a longer duration. The standard deviations obtained between the triplicate groups in the 2 independent challenges were \pm 10 and $19 \%$, which are larger than desired. However, with in vivo evaluations there is inherent variability due to the interactions between the host, environment, and pathogen. The best measure to reduce this variation is to control these factors to the extent possible and increase the number of replicate groups.

The challenge model was used to test the hypothesis that Genomovar I Flavobacterium columnare isolates were more virulent in rainbow trout than Genomovar II isolates because of their apparent species specificity. The results demonstrated that the CPM of rainbow trout challenged with Genomovar II isolates was significantly higher than that obtained with Genomovar I isolates. Previous research has also demonstrated an association between genetic groups of $F$. columnare and virulence. Soto et al. (2008) described 2 genetic groups (A and B) using pulsed-field gel electrophoresis and demonstrated that Group A isolates were more virulent in channel catfish than Group B isolates. Similarly, Shoemaker et al. (2008) demonstrated that Genomovar II isolates are more virulent in channel catfish than Genomovar I isolates. Although no data were presented, Olivares-Fuster et al. (2011) indicated that Genomovar II isolates are more virulent in zebrafish Danio rerio. The results of the present study provide further support for increased virulence of Genomovar II isolates in another fish species, and this is the first time that this has been demonstrated at a colder water temperature $\left(16^{\circ} \mathrm{C}\right)$. The virulence of additional isolates from both genomovars in rainbow trout should be investigated to verify this because Michel et al. (2002) challenged 10 rainbow trout with a Genomovar II isolate and observed no mortality using challenge conditions similar to those in the present study. The fish used in that study were much larger (mean mass $30 \mathrm{~g}$ ) than the fish used in the present study, and this may explain the differing results. Additionally, Suomalainen et al. (2006b) evaluated the virulence of 8 Genomovar I F. columnare isolates, with different automated ribosomal intergenic spacer analysis genotypes (Suomalainen et al. 2006a), in rainbow trout and demonstrated that CPM ranged from less than 25 to $100 \%$. It is possible that the 2 Genomovar I isolates used in the present study (051-10-S5 and ARS-1) are less virulent Genomovar I isolates in rainbow trout. However, F. columnare isolate ARS-1 was included because it demonstrated a higher virulence (CPM of $46 \%$ ) in channel catfish fry compared with the other Genomovar I isolates examined (Shoemaker et al. 2008). Isolate 051-10-S5 was used in the genomovar virulence comparison as an internal control to further determine the reproducibility of the challenge model and to include a rainbow trout isolate that was previously shown to be virulent for rainbow trout. 
The 6 Flavobacterium columnare isolates obtained from rainbow trout in the present study were determined to be Genomovar I following RFLP analysis of the 16S rRNA gene. This result provides further evidence for an apparent host-specific association between Genomovar I F. columnare isolates and salmonids. Other research has also suggested host-specific associations between F. columnare genetic groups and fish species. Thomas-Jinu \& Goodwin (2004) analyzed 17 isolates from 6 different fish species using random amplified polymorphic DNA analysis and 3 groups were identified. This analysis segregated the isolates to some extent by the fish host from which the isolates originated; Group A included isolates from channel catfish, Group B included isolates primarily from cyprinid species, and Group C included isolates from non-cyprinind and non-channel catfish species. Olivares-Fuster et al. (2007a) demonstrated a host-specific association between Genomovar I isolates and threadfin shad Dorosoma pretenense following isolation of $F$. columnare from wild fish in the Mobile River (Alabama, USA). In contrast, Schneck \& Caslake (2006) analyzed 10 F. columnare isolates originating from cold and warm water temperatures and found no association between water temperature and genomovar. However, all of the salmonid isolates analyzed were Genomovar I (Schneck \& Caslake 2006). Further research on a larger number of isolates is needed to investigate the molecular diversity of $F$. columnare from rainbow trout in the United States and other salmonids worldwide to determine whether such a host-specific association between salmonids and Genomovar I F. columnare isolates exists.

Research conducted to determine the molecular diversity of Flavobacterium columnare from rainbow trout in the United States and other salmonid species worldwide should also investigate the occurrence of F. columnare genomovars in the rearing environment and/or source water. In other aquaculture and natural environments, multiple genomovars are present. Triyanto et al. (1999) demonstrated the presence of all 3 genomovars in common carp Cyprinus carpio cultured in tanks supplied with lake water, and all 3 genomovars have been identified in cultured channel catfish in the United States (Darwish \& Ismaiel 2005). In the natural environment, Olivares-Fuster et al. (2007a) demonstrated the presence of Genomovar I and II isolates in different fish species from the Mobile River (Alabama, USA). If such research determines that Genomovar II isolates are not prevalent and/or present in salmonid aquaculture, the results of the present study suggest that introduction of
Genomovar II isolates may negatively impact trout production by increasing mortality due to columnaris disease.

In summary, a reproducible challenge model for columnaris disease has been developed that will aid in further defining the association and virulence of Flavobacterium columnare genomovars in rainbow trout. Further, this model will be useful to investigate host-pathogen interactions, vaccine development, and other potential control strategies.

Acknowledgements. The authors thank Ning Qin and Paige Mumma of USDA-ARS for technical assistance. This research was supported by USDA-ARS CRIS Project No. 6420-32000-024-00D (Integrated Aquatic Animal Health Strategies) and Cooperative Research and Development Agreement (CRADA No. 58-3K95-6-1133) between Merck Animal Health and USDA-ARS. Mention of trade names or commercial products in this publication is solely for the purpose of providing specific information and does not imply recommendation or endorsement by the United States Department of Agriculture.

\section{LITERATURE CITED}

Arias CR, Welker TL, Shoemaker CA, Abernathy JW, Klesius PH (2004) Genetic fingerprinting of Flavobacterium columnare isolates from cultured fish. J Appl Microbiol 97:421-428

Avendaño-Herrera R, Gherardelli V, Olmos P, Godoy MG, Heisinger A, Fernandez J (2011) Flavobacterium columnare associated with mortality of salmonids farmed in Chile: a case report of two outbreaks. Bull Eur Assoc Fish Pathol 31:36-44

Bernardet JF, Segers P, Vancanneyt M, Berthe F, Kersters K, Vandamme P (1996) Cutting a gordian knot: emended classification and description of the genus Flavobacterium, emended description of the family Flavobacteriaceae, and proposal of Flavobacterium hydatis nom. nov. (basonym, Cytophaga aquatilis Strohl and Tait 1978). Int J Syst Bacteriol 46:128-148

- Darwish AM, Ismaiel AA (2005) Genetic diversity of Flavobacterium columnare examined by restriction fragment length polymorphism and sequencing of the $16 \mathrm{~S}$ ribosomal RNA gene and the 16S-23S rDNA spacer. Mol Cell Probes 19:267-274

Davis HS (1922) A new bacterial disease of fresh-water fishes. Bull US Bur Fish 38:261-280

Decostere A, Haesebrouck F, Devriese LA (1997) Shieh medium supplemented with tobramycin for selective isolation of Flavobacterium columnare (Flexibacter columnaris) from diseased fish. J Clin Microbiol 35:322-324

Kunttu HMT, Suomalainen LR, Jokinen EI, Valtonen ET (2009) Flavobacterium columnare colony types: connection to adhesion and virulence? Microb Pathog 46:21-27

LaFrentz BR, Klesius PH (2009) Development of a culture independent method to characterize the chemotactic response of Flavobacterium columnare to fish mucus. J Microbiol Methods 77:37-40

Michel C, Messiaen S, Bernardet JF (2002) Muscle infections in imported neon tetra, Paracheirodon innesi 
Myers: limited occurrence of microsporidia and predominance of severe forms of columnaris disease caused by an Asian genomovar of Flavobacterium columnare. J Fish Dis 25:253-263

Morris JM, Snyder-Conn E, Foott JS, Holt RA and others (2006) Survival of Lost River suckers (Deltistes luxatus) challenged with Flavobacterium columnare during exposure to sublethal ammonia concentrations at pH 9.5. Arch Environ Contam Toxicol 50:256-263

Olivares-Fuster O, Baker JL, Terhune JS, Shoemaker CA, Klesius PH, Arias CR (2007a) Host-specific association between Flavobacterium columnare genomovars and fish species. Syst Appl Microbiol 30:624-633

Olivares-Fuster O, Bullard SA, McElwain A, Llosa MJ, Arias CR (2011) Adhesion dynamics of Flavobacterium columnare to channel catfish Ictalurus punctatus and zebrafish Danio rerio after immersion challenge. Dis Aquat Org 96:221-227

Olivares-Fuster O, Shoemaker CA, Klesius PH, Arias CR (2007b) Molecular typing of isolates of the fish pathogen, Flavobacterium columnare, by single-strand conformation polymorphism analysis. FEMS Microbiol Lett 269: 63-69

Ordal EJ, Rucker RR (1944) Pathogenic myxobacteria. Proc Soc Exp Biol Med 56:15-18

Schneck JL, Caslake LF (2006) Genetic diversity of Flavobacterium columnare isolated from fish collected from warm and cold water. J Fish Dis 29:245-248

Shoemaker CA, Arias CR, Klesius PH, Welker TL (2005) Technique for identifying Flavobacterium columnare using whole-cell fatty acid profiles. J Aquat Anim Health $17: 267-274$

Shoemaker CA, Olivares-Fuster O, Arias CR, Klesius PH (2008) Flavobacterium columnare genomovar influences

Editorial responsibility: Alex Hyatt, Geelong, Victoria, Australia mortality in channel catfish (Ictalurus punctatus). Vet Microbiol 127:353-359

Soto E, Mauel MJ, Karsi A, Lawrence ML (2008) Genetic and virulence characterization of Flavobacterium columnare from channel catfish (Ictalurus punctatus). J Appl Microbiol 104:1302-1310

Suomalainen LR, Tiirola MA, Valtonen ET (2005) Influence of rearing conditions on Flavobacterium columnare infection of rainbow trout, Oncorhynchus mykiss (Walbaum). J Fish Dis 28:271-277

Suomalainen LR, Kunttu H, Valtonen ET, Hirvelä-Koski V, Tiirola M (2006a) Molecular diversity and growth features of Flavobacterium columnare strains isolated in Finland. Dis Aquat Org 70:55-61

Suomalainen LR, Tiirola M, Valtonen ET (2006b) Chondroitin AC lyase activity is related to virulence of fish pathogenic Flavobacterium columnare. J Fish Dis 29:757-763

$>$ Thomas-Jinu S, Goodwin AE (2004) Morphological and genetic characteristics of Flavobacterium columnare isolates: correlations with virulence in fish. J Fish Dis 27: 29-35

> Triyanto, Kumamaru A, Wakabayashi H (1999) The use of PCR targeted 16S rDNA for identification of genomovars of Flavobacterium columnare. Fish Pathol 34:217-218

> Triyanto, Wakabayashi H (1999) Genotypic diversity of strains of Flavobacterium columnare from diseased fishes. Fish Pathol 34:65-71

- Wagner BA, Wise DJ, Khoo LH, Terhune JS (2002) The epidemiology of bacterial diseases in food-size channel catfish. J Aquat Anim Health 14:263-272

Welker TL, Shoemaker CA, Arias CR, Klesius PH (2005) Transmission and detection of Flavobacterium columnare in channel catfish Ictalurus punctatus. Dis Aquat Org 63:129-138

Submitted: March 13, 2012; Accepted: August 16, 2012

Proofs received from author(s): November 1, 2012 